DOI https://doi.org/10.30525/978-9934-26-004-9-14

\title{
CREATIVE INDUSTRIES: CURRENT STATE AND PROSPECTS OF DEVELOPMENT IN UKRAINE
}

\author{
Pletsan H. V. \\ Candidate of Science in Public Administration, Associate Professor, \\ Associate Professor at the Faculty of Hotel, \\ Restaurant and Tourism Business \\ Kyiv National University of Culture and Arts \\ Kyiv, Ukraine
}

Modern globalization trends in the development of socio-cultural environment as a complex, multilevel formation, the main characteristics of which are time, movement and space of social realities and the reset of thinking of Ukrainian society dictate new conditions for cultural activities. In this context, there are questions of the need to identify universal patterns of culture and justify the development of a new paradigm of cultural capital of Ukraine, which should be based on the formation and development of innovative and creative nature of the cultural space.

Given these positions, it is conceptually important to develop and disseminate creative industries as a driving component of the cultural sphere, which have significant potential for cultural diversity, influencing human development, synergistically combining culture, traditions, cultural values, culture and personality, culture and society, innovative ideas and information technologies.

Formation and development of creative industries in Ukraine have their respective historical, cultural and original specifics. In Ukraine, the concept of cultural and creative industries received partial «state recognition» only in the summer of 2018, when the Verkhovna Rada decided to provide a legal definition of the term «creative industries», thus de jure emphasizing the importance of supporting cultural development. The «Long-Term National Strategy for the Development of Culture until 2025» focuses on supporting the growth of the creative industries sector.

New realities of today - new challenges for the creative industries of Ukraine. In general, the sphere of creative industries plays a threefold role in the national innovation process: by definition it is the main source of innovative ideas and the emergence of new goods and services; offer services that can be a resource for innovation of other enterprises, which belong or do 
not belong to the creative sector; intensively use new technologies and often require their counterparties to adapt to changes in market demand, the introduction of technological changes, thereby forming innovative impulses for technology manufacturers, as determined by the specifics of creative industries.

The development of creative industries, on the one hand, provides mobility, access to the global market, forms project thinking, uses many different resources, promotes human individuality and trust in society, and on the other - promotes the development and preservation of culture, history and traditions, formation of creative environment.

The priority in the development of creative industries of Ukraine is the effective cooperation of Ukraine with European partners in the field of culture, which is focused on promoting intercultural dialogue, cultural exchange, increasing the mobility of art objects, etc. In particular, the EU-Eastern Partnership Culture and Creativity program aims to support the cultural and creative sectors and increase their contribution to sustainable economic, social and humanitarian development. An important step is Ukraine's participation in the EU's Creative Europe program, which allows Ukrainian cultural institutions to join European professional networks, find partners and implement various joint international projects. In particular, the projects «Honchar's Museum - Creative Europe», «Tustan - Creative Europe». The main components of the programs are practical research, trainings, information campaigns and opportunities for dialogue with the international community.

The creative potential of Ukrainians is aimed at ensuring the development of cultural heritage and the creative sector of the economy, seeking the support of the authorities at both state and regional levels. Today, creativity is a necessity of the modern cultural process; it is an opportunity for selfrealization, the release of the creative potential of the individual in the culture of professional spheres of activity. In general, it is a tool for finding innovative solutions, cultural values, effective use of cultural diversity of the nation's heritage and resources, identification of universal cultural patterns, mass culture in general.

The power of the creative sphere, which gives the opportunity through the power of cultural products to form the brand of Ukraine and ensure promotion in the world.

Every day the publishing activity develops, diversifying the modern types of the publishing industry and introducing innovations with the use of digitalization.

The geography of sales of original, very original, competitive, high-quality products of Ukrainian designers is expanding. There are four national film 
studios in Ukraine. Expanded range of cultural and digital services, constantly developing advertising and public relations. Over the past 5 years, 110 Ukrainian films have been released, which has contributed to the popularization of the achievements of domestic cinema not only in domestic but also in international film distribution, raising the country's image. Thus, confirming that cinema can help to promote Ukraine with the help of culture.

Culture and creative industries are developing through the prism of intangible cultural heritage, which is a major factor in the cultural identity of the state and contributes to the recognition of unique traditions (customs, rituals) and cultural monuments of Ukraine as masterpieces of World Heritage. Cathedral of saint Sophia, Kyivo-Pecherska Lavra, Historical center of Lviv, Beech virgin forests of the Carpathians, Cross-border object «Druha Struve» Residence of the Metropolitans of Bukovina and Dalmatia, Wooden churches of the Carpathian region, the ancient city of Chersonese, etc.). The main source of potential competitiveness of the country is the identification of Ukraine in the world through its brands, in particular Kosovo ceramics, Petrykivka painting, Borshchiv embroidered shirt, etc.

The main challenge of the modern music industry is the widespread use of new technologies and techniques, which has led to new trends in the implementation and promotion of cultural music product. One of the powerful promotional tools to increase the popularity of the Ukrainian cultural industry was the success of Ukraine at Eurovision in 2004, 2016 and during the competition in Ukraine. «Shchedryk» remains the musical brand of Ukraine as the most popular brand of Ukrainian song in the world. In turn, Ukrainian young artists see Ukrainian culture as a modern trend.

Increased attention to the development of gastronomy. For example, the famous Ukrainian borscht was included in the preliminary list of UNESCO for possible inclusion in the list of intangible cultural heritage of mankind. We are convinced that the promotion of Ukrainian cuisine will expand cooperation at the international level.

With the support of the Ukrainian Cultural Foundation, the cultural sector is implementing powerful projects that increase the flow of tourists, attract investors, and provide international partnerships. In particular, the concept of revitalization of the historical and cultural monument of Svirzh Castle (allowed to open a historical and cultural monument for visitors for the first time in 50 years), the inclusive project «Those who conquered the darkness» (with Lithuanian and Ukrainian performers with severe visual impairments, with the involvement of the orchestra of the Lviv National Theater named after M. Zankovetska), the festival «Vertep-Fest» (attracted more than 50 nativity theaters, folklore and theater groups and amateur associations from all 
ethnographic regions of Ukraine), the project «October in October» (creative hub - a modern cultural center, which would be the result of holding an urban festival on the site), etc.

We also focus on effective and creative work with newsmakers through the means of cultural and artistic analysis and the presentation of Ukrainian culture in the world as self-sufficient and original.

An important aspect of the development of the creative industry is the investment platform. As the Minister of Culture and Information Policy Oleksandr Tkachenko said in his speech at the Creative Ukraine forum: «Without investment in the creative industries in Ukraine there is no future. One of our main tasks is to recognize the importance of creative entrepreneurs and invest in the creative industries». The focus of support is creative hubs of all spheres of creative industries of Ukraine.

We are convinced that the formation of a new model of creative industries in Ukraine is based on constant cooperation that will ensure the establishment of a dialogue between: creative personality (creator) - business - civil society - the state. The conceptual foundations of the development and dissemination of creative industries need to be rethought. There is a need to create a creative digital industry, implementing a creative product through digitalization. In addition, one cannot ignore the multifaceted cultural identities for which Ukraine has become a home: cities, villages, unique examples of cultural heritage, works of different nationalities. Understanding and disseminating a creative way of life, promoting the self-realization of our citizens - is the basis of the country's competitiveness, increasing its position in global rankings and obtaining a specific economic effect.

The current crisis in the world in general and in the creative industries in particular is a culture shock and has proved that not only the future of business depends on the transition to digital technologies, but also the current one is at stake if we do not act quickly. That is why we need to realize that culture and creative industries are changing, there is collaboration in all areas to achieve a successful result. At the same time, we focus on man and his creativity, as well as on the need, in accordance with the challenges of the time, to form a cluster of creative and cultural industries.

Summarizing the above, we note that the prospects for the development of creative industries in Ukraine are certainly strong. The priority ways of optimization and modernization of creative industries include: long-term support of the government at the state and regional levels; receiving grants for institutional support; improvement of regulatory and legal support; simplification of the mechanisms of the procedural system; formation of a competitive cultural manager; attracting investment in the creative industries; 
ensuring an effective system of digitalization of cultural products; realization of the value of ecosystems of creative enterprises; formation of effective mechanisms to stimulate the development of the environment of creative industries; initiating the creation of a fund of startups; ensuring development through self-expression; implementation of innovative programs for modernization of creative industries to make Ukraine the most creative and convenient for everyone. After all, «Ukraine inspires you, you inspire literature, literature inspires ballet, ballet inspires cinema, cinema inspires music, music inspires folk crafts, folk crafts inspire fashion, fashion inspires design, design inspires technology, technology inspires you, Ukraine inspires you, Ukraine inspires the world !!!»

\section{References:}

1. Karasova N. A. Kreatyvni industrii yak element stratehii postindustrialnoho rozvytku. Mizhnarodni vidnosyny: teoretyko-praktychni aspekty. 2019. Vyp. 3. S. 110-120.

2. Loshkovska Kh. S. Kreatyvni industrii yak suchasnyi sehment stratehichnoho rozvytku krain svitu. URL: http://meim.kneu.edu.ua. (дата звернення: 20.11.2020).

3. Kathrin Müller, Christian Rammer, and Johannes Trüby. The Role of Creative Industries in Industrial Innovation. URL: ftp://ftp.zew.de/pub/zewdocs/dp/dp08109.pdf. (дата звернення: 20.11.2020).

4. UN Creative economy report (2010) «Creative economy: a feasible development opinion». URL: http://unctad.org/es/Docs/ditctab20103 en.pdf. (дата звернення: 20.11.2020).

5. UN Creative economy report (2019) «Creative Economy Outlook: Trends in international trade in creative industries». URL: https://unctad.org/system/files/official-document/ditcted2018d3 en.pdf. (дата звернення: 20.11.2020). 